\title{
ANALISIS KESALAHAN SISWA DALAM MENGERJAKAN SOAL TIMMS UNTUK KATEGORI PENALARAN
}

\author{
Evi Widayanti, Intan Aulia Kolbi \\ Pendidikan Matematika STKIP Bina Insan Mandiri Surabaya
}

\begin{abstract}
This research aims to describe in detail the errors of students in doing TIMSS question and describe the factors that cause students to experience errors in the TIMSS for reasoning category in 8th grade. The research using descriptive qualitative approach. The subjects were 8th-grade students of SMP Al-Karimah Surabaya Data collection techniques used include tests, interviews, and documentation. While the object in this research is the test results of students of class VIII SMP Al-Karimah Surabaya in working TIMSS in Mathematics 2011 for the category of reasoning. The results of the error analysis of students in TIMSS 2011 can be summarized as follows: mistakes made by students are grouped into 3 types: a) Concept errors, b) Errors procedures, and c) Calculation error. In doing the TIMSS 2011 on reasoning category, the type of error that most students experience is a mistake in understanding the concept.
\end{abstract}

Keywords: Mistake; TIMSS; Reasoning

\section{PENDAHULUAN}

Handi (2016) menyatakan bahwa tingkat pendidikan suatu negara dapat mencerminkan kemajuan negara yang bersangkutan. Tingkat pendidikan akan berpengaruh terhadap kemampuan menguasai ilmu pengetahuan dan teknologi serta sikapnya terhadap kemajuan jaman. Hal ini menjelaskan bahwa pendidikan adalah sarana penting untuk meningkatkan kualitas suatu negara.

Salah satu kegiatan survei internasional yang memantau kualitas pendidikan suatu negara adalah Trends in International Mathematics and Science Study (TIMSS) yang dilakukan International Association for the Evaluation of Educational Achievement (IEA). IEA merupakan organisasi yang bergerak di bidang penilaian dan pengukuran pendidikan. TIMSS telah memantau dalam pencapaian matematika dan sains setiap empat tahun, khususnya siswa usia 14 tahun pada jenjang SMP. Rohmani (2017) menjelaskan bahwa penilaian TIMSS berfokus pada materi yang termuat dalam kurikulum sekolah dan didesain untuk mengukur seberapa jauh kualitas perkembangan siswa sesuai dengan kurikulum.

Kemampuan penalaran siswa Indonesia masih tergolong rendah. Hal ini terlihat dari hasil TIMSS di tahun 2011, dimana dilaporkan bahwa Indonesia berada di urutan ke-38 
dari 42 negara dengan perolehan skor rata-rata 386 (Mullis, Martin, Foy, \& Arora, 2012). Tjalla (2010) menyatakan bahwa rendahnya hasil tersebut disebabkan beberapa hal. Salah satunya adalah siswa Indonesia kurang terbiasa menyelesaikan soal-soal pemecahan masalah yang menuntut kemampuan penalaran siswa. Dalam proses pembelajaran matematika di Indonesia, guru terlalu berkonsentrasi pada latihan penyelesaian soal yang lebih bersifat mekanistik dan prosedural, sedangkan latihan penyelesaian soal yang bersifat penalaran sangat kurang.

Berdasarkan data survei di atas, muncul pertanyaan apa yang membuat pelajar Indonesia mengalami kesulitan dan kesalahan apa yang dialami siswa dalam mengerjakan soal-soal TIMSS Matematika kategori penalaran. Oleh karena itu, perlu dilakukan analisis terhadap kesalahan-kesalahan siswa dalam mengerjakan soal TIMSS Matematika kategori penalaran supaya kesalahan-kesalahan tersebut diketahui oleh guru sehingga guru bisa melakukan tindakan yang tepat kepada siswanya dan hasil penilaian TIMSS terhadap siswa Indonesia bisa lebih baik.

Komarudin (2016) menyatakan bahwa tipe kesalahan yang sering dialami siswa dalam mengerjakan soal pemecahan masalah materi peluang antara lain, kesalahan dalam menentukan apa yang diketahui dan ditanyakan, tidak menuliskan langkah-langkah yang digunakan sesuai permasalahan, tidak menuliskan rumus yang digunakan, tidak menuliskan kesimpulan, dan tidak melakukan perhitungan ketika memeriksa kembali solusi. Sedangkan Rohmani (2017) menyatakan bahwa pada soal pilihan ganda, siswa paling banyak mengalami kesalahan menjawab karena terkecoh oleh distraktor salah konsep sebesar 20.44\%, terkecoh karena salah hitung sebesar 7.686\% dan terkecoh karena distraktor aspek kurang teliti sebesar 5.659\%. Sedangkan untuk soal uraian, siswa paling banyak melakukan kesalahan pada tipe kesalahan memahami masalah sebanyak $86 \%$, tipe kesalahan transformasi sebanyak $74 \%$, dan tipe kesalahan ketrampilan proses sebanyak $74 \%$, serta untuk tipe kesalahan penulisan sebanyak $69 \%$.

BSNP (2016) menerangkan kemampuan penalaran matematis merupakan salah satu komponen yang penting yang perlu dilatihkan kepada siswa. Van de Walle, Karb, \& BayWilliams mengungkapkan bahwa siswa perlu mengembangkan kebiasaan menggunakan kemampuan penalaran dalam setiap menyelesaikan masalah (Wahyudi, Zulkardi, Darmawijoyo, 2016). Pentingnya kemampuan ini juga terlihat dari Permendiknas No. 22 Tahun 2006 yang menyatakan salah satu tujuan pembelajaran matematika untuk satuan 
pendidikan dasar dan menengah adalah menggunakan penalaran pada pola dan sifat, melakukan manipulasi matematika dalam membuat generalisasi, menyusun bukti, atau menjelaskan gagasan dan pernyataan matematika (BSNP, 2016).

\section{METODE PENELITIAN}

Penelitan ini menggunakan pendekatan deskriptif kualitatif. Subjek dalam penelitian ini adalah siswa kelas VIII SMP Al-Karimah Surabaya Tahun Pelajaran 2017/2018 sebanyak 15 siswa. Sedangkan objek dalam penelitian ini adalah hasil tes siswa dalam mengerjakan soal TIMSS Matematika tahun 2011 kategori penalaran. Kelas VIII dipilih sebagai subjek penelitian karena soal TIMSS yang digunakan berlaku untuk kelas VIII. Selain itu, mereka memiliki kemampuan belajar yang baik.

Instrumen penelitian yang digunakan meliputi: a) pedoman wawancara, berupa buku catatan dan voice recorder; b) dokumentasi, dan c) lembar tes, berupa lembar kerja individu berisi soal TIMSS Matematika Tahun 2011 sebanyak 8 butir soal. Teknik pengumpulan data berupa tes, wawancara, dan dokumentasi. Analisis data dilakukan dalam 3 tahap, yaitu: data reduction (reduksi data), data display (penyajian data), dan conclusion drawing (menarik kesimpulan).

\section{HASIL DAN PEMBAHASAN}

Hasil penelitian jenis kesalahan siswa dalam menyelesaikan soal TIMSS Matematika tahun 2011 kategori penalaran disajikan pada Tabel 1 berikut.

Tabel 1. Jenis Kesalahan Siswa dalam Soal TIMSS Matematika

\begin{tabular}{cccccccccc}
\hline \multirow{2}{*}{ No. } & \multirow{2}{*}{ Nama } & \multicolumn{10}{c}{ Nomor Soal } \\
\cline { 3 - 10 } & & 1 & 2 & 3 & 4 & 5 & 6 & 7 & 8 \\
\hline 1 & MR & SH & B & B & B & SP & SK & SH & B \\
2 & ES & SK & SH & SP & B & SP & SK & B & SP \\
3 & IN & SK & SK & SP & SP & B & SK & B & SK \\
4 & B & SK & SK & SH & B & SK & B & SK & SP \\
5 & KS & B & SK & SH & B & SH & B & SP & SP \\
6 & Y & SK & SK & SP & SP & SK & SK & B & SP \\
7 & MRM & SK & SK & SP & B & SK & B & SK & SP \\
8 & A & SK & SK & SH & SP & SK & SK & B & B \\
9 & AS & SH & B & SP & SP & SP & SK & B & SH \\
10 & AW & SK & SH & SP & SP & SP & SK & SP & SH \\
11 & NK & SK & SH & SH & B & SP & SK & B & B \\
12 & SR & SK & B & B & SP & SP & SK & B & B \\
13 & U & SK & B & SP & B & SK & SK & B & SP \\
14 & NE & SK & B & SP & SP & SP & SK & B & SP
\end{tabular}




\begin{tabular}{|c|c|c|c|c|c|c|c|c|c|}
\hline \multirow{2}{*}{ No. } & \multirow{2}{*}{ Nama } & \multicolumn{8}{|c|}{ Nomor Soal } \\
\hline & & 1 & 2 & 3 & 4 & 5 & 6 & 7 & 8 \\
\hline 15 & $\mathrm{AK}$ & SP & SK & SH & $\mathrm{SP}$ & SK & SK & B & SP \\
\hline
\end{tabular}

Keterangan: $\mathrm{B}=$ benar; $\mathrm{SK}=$ salah konsep; $\mathrm{SP}=$ salah prosedur; $\mathrm{SH}=$ salah hitung.

Berdasarkan Tabel 1, didapatkan hasil 33 soal diselesaikan dengan benar, 39 soal diselesaikan dengan salah konsep, 34 soal diselesaikan dengan salah prosedur, dan 14 soal diselesaikan dengan salah hitung. Total kesalahan siswa dalam menyelesaikan soal TIMSS adalah 87 kesalahan (72.5\%) dari 120 soal yang dikerjakan oleh 15 siswa, dimana masing-masing siswa menyelesaikan 8 soal TIMSS yang sama. Adapun persentase kesalahan siswa sebagai berikut: kesalahan siswa dalam pemahaman konsep $\frac{39}{87} \times 100 \%=$ $44.83 \%$, kesalahan siswa dalam melakukan prosedur $\frac{34}{87} \times 100 \%=39.08 \%$, dan kesalahan siswa dalam melakukan perhitungan $\frac{14}{87} \times 100 \%=16.09 \%$.

Berikut ini dideskripsikan jenis kesalahan masing-masing pada setiap soal.

\section{Soal Nomor 1}

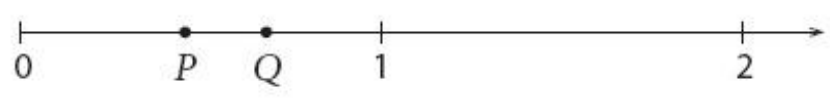

$\mathrm{P}$ dan $\mathrm{Q}$ mewakili 2 bagian pada garis bilangan di atas. $\mathrm{P} \times \mathrm{Q}=\mathrm{N}$.

Manakah yang menunjukkan lokasi N pada garis bilangan?

a.

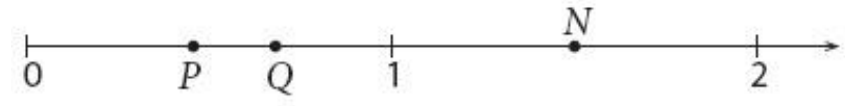

b.

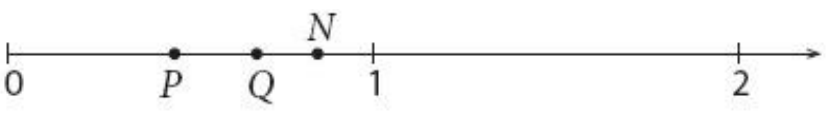

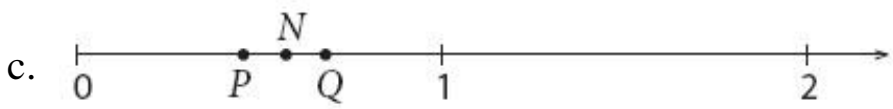

d.

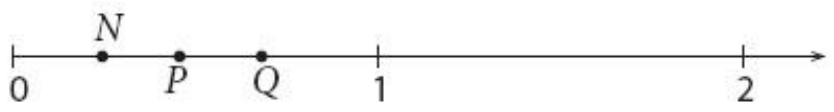

Pada soal nomor 1, terdapat 14 siswa melakukan kesalahan, di antaranya 11 siswa salah dalam pemahaman konsep, 1 siswa melakukan kesalahan dalam mengambil langkah, dan 2 siswa melakukan kesalahan dalam berhitung. Dalam tahap pemahaman konsep yang masih terjadi kesalahan, mayoritas siswa mengaku bahwa mereka kebingungan dengan adanya variabel $\mathrm{P}, \mathrm{Q}$, dan $\mathrm{N}$ karena mereka masih terbiasa dengan adanya bilangan-bilangan dalam operasi perkalian dan garis bilangan. Untuk siswa yang melakukan kesalahan dalam mengambil prosedur penyelesaian dan dalam berhitung, 
mereka tidak teliti adanya bilangan 1 dan 2 pada garis bilangan. Sehingga mereka berasumsi bahwa $\mathrm{P}$ dan $\mathrm{Q}$ merupakan bilangan asli, sehingga jika dikalikan hasilnya lebih besar. 


\section{Soal Nomor 2}

Letakkan 4 digit 3, 5, 7, dan 9 ke dalam kotak-kotak di bawah pada posisi yang dapat memberikan hasil terbesar ketika 2 angka dikalikan dengan 2 angka lainnya.

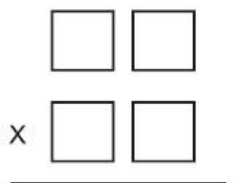

Pada soal nomor 2, terdapat 10 siswa melakukan kesalahan, di antaranya 7 siswa salah dalam pemahaman konsep, dan 3 siswa melakukan kesalahan dalam berhitung. Siswa memberikan pernyataan bahwa mereka hanya memahami sepenggal kalimat dalam soal, yaitu meletakkan 4-digit angka ke dalam kotak. Sedangkan mereka tidak paham dengan perintah soal untuk meletakkan 4-digit itu sehingga menghasilkan nilai yang paling besar. Sehingga banyak siswa yang meletakkan 4-digit tersebut secara acak atau asal-asalan.

\section{Soal Nomor 3}

Jo memiliki 3 balok logam. Berat setiap balok adalah sama. Ketika dia menimbang 1 balok dengan timbel 8 gram, ini yang terjadi:

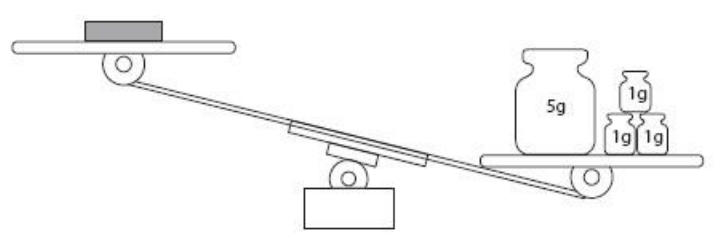

Ketika dia menimbang semua 3 balok dengan timbel 20 gram, ini yang terjadi:

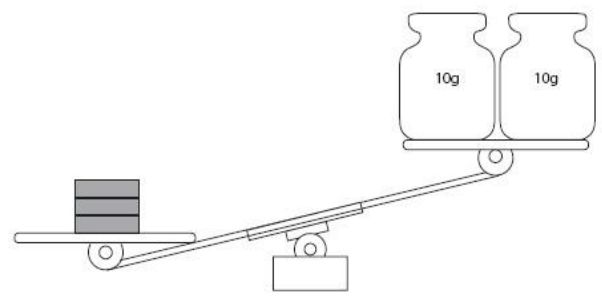

Manakah berikut yang merupakan berat 1 balok logam?
a. $5 \mathrm{~g}$
c. $7 \mathrm{~g}$
b. $6 \mathrm{~g}$
d. $8 \mathrm{~g}$

Pada soal nomor 3, terdapat 13 siswa melakukan kesalahan, diantaranya 8 siswa salah dalam tahap prosedural dan 5 siswa yang melakukan kesalahan dalam berhitung. Dalam soal ini, siswa melakukan kesalahan dikarenakan siswa mampu memahami pada gambar pertama yaitu timbangan 1 balok dengan timbel 8 gram. Dari gambar tersebut 
mereka mampu menyimpulkan bahwa berat 1 balok kurang dari 8 gram. Namun pada gambar ke-dua mereka mengalami kebingungan, sehingga siswa menjawab asal pilihan ganda dimana berat timbel kurang dari 8 gram.

\section{Soal Nomor 4}

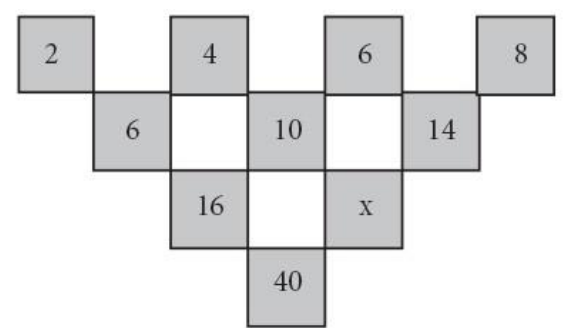

Berapa nilai x pada pola ini?

Pada soal nomor 4, terdapat 8 siswa melakukan kesalahan, dimana 8 siswa tersebut melakukan kesalahan dalam prosedural. Jawaban yang benar pada soal nomor 4 adalah 24 didapat dari $10+14$. Namun, masih banyak siswa yang salah merumuskan pola. Mereka beranggapan bahwa pola untuk baris pertama adalah pola deret kelipatan dari 2 , baris kedua kelipatan dari 4, dan baris ketiga merupakan kelipatan dari 6, sehingga siswa menjawab nilai $\mathrm{x}$ adalah 22 .

\section{Soal Nomor 5}

Titik A, B, dan $C$ berada di sebuah garis dan $B$ ada di antara $A$ dan C. Jika $A B=10 \mathrm{~cm}$ dan $\mathrm{BC}=5.2 \mathrm{~cm}$, berapa jarak antar titik tengah dari $\mathrm{AB}$ dan $\mathrm{BC} ?$
a. $2.4 \mathrm{~cm}$
c. $5.0 \mathrm{~cm}$
b. $2.6 \mathrm{~cm}$
d. $7.6 \mathrm{~cm}$

Pada soal nomor 5, terdapat 14 siswa melakukan kesalahan, dimana 6 siswa tersebut melakukan kesalahan dalam memahami konsep, 7 siswa salah melakukan langkahlangkah penyelesaian, dan 1 siswa yang salah dalam perhitungan. Banyak siswa yang tidak memahami maksud soal, dikarenakan siswa kebingungan dan tidak mampu mengilustrasikan deskripsi pada soal untuk dituangkan ke dalam gambar. Selain itu, siswa juga melakukan kesalahan prosedur, yaitu asal mengoperasikan angka-angka yang terdapat pada soal. 


\section{Soal Nomor 6}

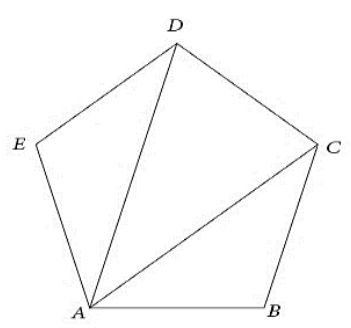

Berapa jumlah semua sudut dalam dari segi-5 ABCDE? Tunjukkan pekerjaanmu!

Pada soal nomor 6, terdapat 12 siswa melakukan kesalahan, dimana 12 siswa tersebut melakukan kesalahan dalam memahami konsep, mereka beranggapan bahwa perintah soal tersebut adalah mencari banyak sudut dalam, bukan mencari jumlah sudut dalam. Sehingga banyak dari mereka yang menjawab 9 sudut.

\section{Soal Nomor 7}

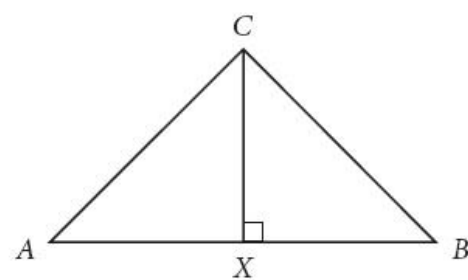

Ini adalah segitiga: $\mathrm{AC}=\mathrm{BC}$. $\mathrm{AB}$ merupakan dua kali panjang $\mathrm{CX}$. Berapa ukuran sudut $\mathrm{B}$ ?

Pada soal nomor 7, terdapat 5 siswa melakukan kesalahan, di antaranya 2 siswa melakukan kesalahan dalam memahami konsep, 2 siswa salah mengambil langkah penyelesaian, dan 1 siswa salah dalam perhitungan. Untuk siswa yang tidak memahami konsep, lebih memilih tidak menjawab soal nomor 7 sedangkan siswa yang melakukan kesalahan prosedur, mengerjakan dengan asal-asalan, mengira-ngira berapa derajat sudut B. Hal ini disebabkan karena siswa belum memahami konsep jumlah sudut dalam segitiga.

\section{Soal Nomor 8}

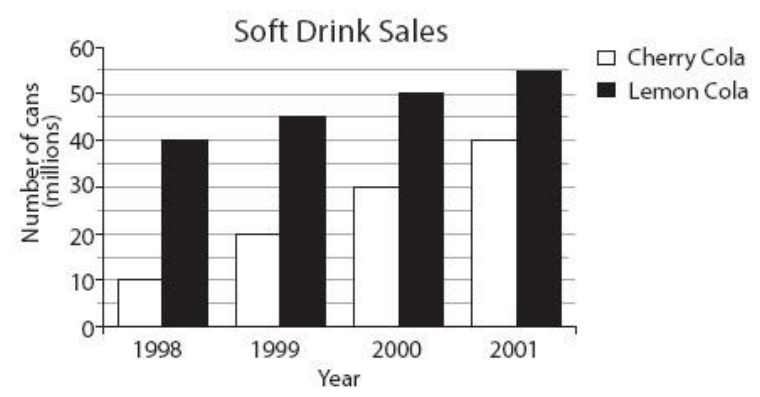


Grafik di atas menampilkan penjualan 2 jenis minuman selama 4 tahun. Jika penjualan berlanjut selama 10 tahun berikutnya, tentukan tahun di mana penjualan Cherry Cola akan sama dengan penjualan Lemon Cola.
a. 2003
c. 2005
b. 2004
d. 2006

Pada soal nomor 8, terdapat 11 siswa melakukan kesalahan, diantaranya 1 siswa melakukan kesalahan dalam memahami konsep, 8 siswa salah mengambil langkah penyelesaian, dan 2 siswa salah dalam perhitungan. Kebanyakan dari siswa salah dalam mengambil langkah awal. Mereka asal mengoperasikan bilangan-bilangan yang terdapat di soal. Misal, 10 tahun dibagi dengan 2 jenis minuman dan akan menghasilkan 5 dan bilangan 5 itu identik dengan tahun 2005.

Berdasarkan hasil penelitian di atas, diperoleh nilai rata-rata tes sebesar 23.33 dengan nilai tertinggi 40 dan nilai terendah 0. Dari data tersebut diperoleh informasi bahwa siswa kelas VIII mengalami kesalahan dalam mengerjakan soal TIMSS 2011 kategori penalaran. Kesalahan yang dilakukan siswa dikarenakan mereka belum mampu memahami konsep soal dan tidak mengikuti langkah-langkah yang harus dilakukan dalam pengerjaan soal sehingga siswa mengalami kesulitan merencanakan penyelesaian. Hal ini sesuai pendapat Cahyono (2016) bahwa dalam menyelesaikan soal pada TIMSS, peserta didik dituntut menggunakan logika dan kemampuan berpikir sistematis termasuk menggunakan penalaran intuitif dan induktif berdasar pada pola-pola yang dapat digunakan untuk memecahkan masalah baru. Oleh karena itu, kesalahan yang sering terjadi pada siswa adalah kesalahan pada konsep.

\section{SIMPULAN DAN SARAN}

Berdasarkan uraian yang telah dipaparkan sebelumnya dan hasil analisis kesalahan siswa dalam mengerjakan soal TIMSS 2011 kategori penalaran kelas VIII disimpulkan bahwa kesalahan-kesalahan yang dilakukan siswa dikelompokkan dalam 3 jenis, yaitu: a) kesalahan konsep, yaitu kesalahan siswa dalam memahami soal, dan siswa tidak paham konsep matematika yang diperlukan, b) kesalahan prosedur, yaitu kesalahan siswa dalam menggunakan konsep matematika, salah dalam mengambil langkah penyelesaian, dan c) kesalahan perhitungan, yaitu kesalahan siswa dalam menuliskan hasil perhitungan. Hal ini menunjukkan bahwa kemampuan siswa dalam mengerjakan soal TIMSS kategori penalaran masih tergolong rendah. Rendahnya nilai rata-rata siswa menunjukkan bahwa 
siswa belum terbiasa dalam mengerjakan soal-soal sejenis TIMSS. Siswa terbiasa dengan soal-soal standaryang prosedural, dimana angka-angka yang disajikan adalah angkaangka yang diperlukan. Jenis kesalahan yang paling banyak dialami adalah kesalahan dalam pemahaman konsep. Siswa belum mampu memahami perintah soal yang diberikan. Mereka seringkali mengalami kebingungan dengan maksud dan tujuan dari soal.

Saran yang dapat digunakan untuk mengatasi kesalahan-kesalahan yang dilakukan siswa kelas VIII dalam menyelesaikan soal TIMSS adalah guru sebaiknya membiasakan siswa untuk mengerjakan soal-soal penalaran, membimbing siswa dalam menuangkan deskripsi dalam teks ke dalam bentuk gambar atau ilustrasi, dan perlu diadakan penelitian lanjutan mengenai kesalahan siswa dalam mengerjakan soal TIMSS Matematika.

\section{DAFTAR RUJUKAN}

BSNP. (2006). Standar Kompetensi dan Kompetensi Dasar SMP/MTs. Jakarta: BSNP.

Cahyono, B. \& Adilah, N. (2016). Analisis soal dalam buku siswa matematika kurikulum 2013 kelas VIII semester 1 berdasarkan dimensi kognitif dari TIMSS. JRPM (Jurnal Review Pembelajaran Matematika), 1(1), 86-98. doi: https://doi.org/10.15642/jrpm.2016.1.1.86-98

Handi, A. (2016). Faktor-faktor yang Mempengaruhi Kualitas Penduduk. (online). http://edukasi.handy.co.id/geografi/pengertian-kualitas-penduduk-adalah/ (diakses tanggal 21 Oktober 2017)

Komaruddin, K. (2016). Analisis kesalahan siswa dalam pemecahan masalah matematika pada materi peluang berdasarkan high order thinking dan pemberian scaffolding. Jurnal Darussalam: Jurnal Pendidikan, Komunikasi dan Pemikiran Hukum Islam, 8(1), 202-217. doi: https://doi.org/10.30739/darussalam.v8i1.96

Mullis, I. V. S., Martin, M. O., Foy, P., \& Arora, A. (2012). TIMSS 2011 international result in mathematics. Chesnut Hill: TIMSS \& PIRLS International Study Center, Boston College.

Rohmani, M. B. N. (2017). Analisis kesalahan siswa dalam mengerjakan soal mirip timss berdasarkan distraktor dan teori kesalahan Newman. Skripsi tidak dipublikasikan. Yogyakarta: FMIPA UNY.

TIMMS \& PIRLS. (2016). About TIMSS and PIRLS International Study Center. (online). https://timssandpirls.bc.edu/about.html (diakses tanggal 30 Oktober 2017)

Tjalla, A. (2010). Potret mutu pendidikan indonesia ditinjau dari hasil-hasil studi internasional. Seminar Nasional FKIP-UT. Perpustakaan Digital UT 
Wahyudi, T. Zulkardi, \& Darmawijoyo. (2016). Pengembangan soal penalaran tipe TIMSS menggunakan konteks budaya lampung. Jurnal Didaktik Matematika, 3(1), $1-14$.

Wardani, S., R. (2011). Instrumen Penilaian Hasil Belajar Matematika SMP: Belajar dari PISA dan TIMSS. Badan Pengembangan Sumber Daya Manusia Pendidikan dan Penjaminan Mutu Pendidikan, Kementerian Pendidikan Nasional. 